\title{
The Summa Halensis: Sources and Context
}

\section{Introduction}

The Franciscan intellectual tradition as it developed before Bonaventure, and above all, Duns Scotus, has not been the subject of much scholarly attention over the years. By most accounts, Bonaventure's forebears, and even Bonaventure himself, worked primarily to systematize the intellectual tradition of Augustine that had prevailed for most of the earlier Middle Ages. ${ }^{1}$ In contrast, Scotus is supposed to have broken with past precedent to develop innovative philosophical and theological positions that anticipated the rise of modern thought. Thus, Scotus and his successors have been the focus of many studies, while his predecessors are deemed largely insignificant for the further history of thought. ${ }^{2}$

This volume and another that accompanies it will make a case for the innovativeness of early Franciscan thought, which the editor has also advanced elsewhere. ${ }^{3}$ The contributions are based on proceedings from four conferences which were held over the course of 2018 and sponsored by the European Research Council. While these conferences concerned the early Franciscan tradition in general, their more specific focus was the so-called Summa Halensis, a massive text that was collaboratively authored by the founding members of the Franciscan school at Paris between 1236 and 1245, in an attempt to lay down a distinctly Franciscan intellectual tradition for the very first time. Although some final additions to the text were made in $1255-6$, the Summa was mostly composed during the second quarter of the thirteenth century and thus within first 50 years of the existence of the University of Paris, which was founded around 1200 and served as the centre for theological study at the time. In countless respects, it laid the foundation for the further development of the Franciscan intellectual tradition

The need for a text like the Summa was precipitated in part by the rapid growth of the Franciscan order-from 12 members in 1209 to as many as 20,000 by 1250-the

\footnotetext{
1 Ignatius Brady, 'The Summa Theologica of Alexander of Hales (1924-1948),' Archivum Franciscanum Historicum 70 (1977): 437-47; Étienne Gilson, The Philosophy of St Bonaventure (Chicago: Franciscan Press, 1965). See also A.-M. Hamelin, L'école franciscaine de ses débuts jusqu'à l'occamisme, Analecta mediaevalia Namurcensia, 12 (Louvain: Nauwelaerts, 1961); Christopher Cullen, Bonaventure (Oxford: Oxford University Press, 2006).

2 Olivier Boulnois, Être et representation: Une généalogie de la métaphysique moderne à l'époque de Duns Scot (Paris: Presses Universitaires de France, 1999); Ludger Honnefelder, Scientia transcendens: Die formale Bestimmung der Seiendheit und Realität in der Metaphysik des Mittelalters und der Neuzeit (Hamburg: Felix Meiner, 1990).

3 The accompanying edited volume is published by De Gruyter under the title, The Summa Halensis: Doctrines and Debates. Lydia Schumacher, Early Franciscan Theology: Between Authority and Innovation (Cambridge: Cambridge University Press, 2019).
} 
most gifted of whom required a basis for their scholarly formation. As a matter of fact, the Summa was the text on which the likes of Bonaventure and Scotus were inducted into their order's intellectual tradition. ${ }^{4}$ Bonaventure, for one, credits everything he learned to his 'master and father' Alexander of Hales, which is scarcely an exaggeration..$^{5}$ As is well documented, the rapid emergence of a scholarly division within the order quickly gave rise to considerable controversy both within and outside of its membership. While some largely lay Franciscans, particularly those who had known Francis, questioned the compatibility of studies with the Franciscan ideal of poverty, the 'secular' masters at the young university, namely, those who were not associated with a religious order, perceived the friars as competitors for students, prestige, and ultimately a threat to their personal salaries.

One of the ways that the Franciscans sought to defend their stake in university life involved attempts to 'out-do' the secular masters in terms of the scope and extent of the theological texts they produced. The Franciscans were aided in this regard by the entrance of Alexander of Hales into the order in 1236, which instigated the production of the Summa Halensis itself. In his already long and distinguished career, Alexander had been celebrated as one of the most sophisticated and significant theologians in the Parisian Faculty of Theology. ${ }^{6}$ As is well known, he championed the effort to give a central place in the university timetable to lectures on Lombard's Sentences, in addition to the Bible. Furthermore, he composed one of the earliest Sentences Commentaries, eventually establishing this practice as the key to obtaining the license to teach theology, the medieval equivalent to the doctoral degree. ${ }^{7}$ By acquiring such a distinguished scholar amongst their ranks, the Franciscans captured their place in the university at a time when higher education was fast becoming the precondition for religious and spiritual authority and thus essential to the very survival of the order. ${ }^{8}$ More immediately, they gained the human resource needed to oversee the project that ultimately resulted in the Summa that bears Hales' name.

Although Alexander certainly oversaw the work of the Summa and contributed a great deal to it, whether indirectly or directly, the editors of the fourth tome, led by Victorin Doucet, eventually clarified that other Franciscans were involved in its composition as well. ${ }^{9}$ This was something that the editors of tomes $1-3$, overseen by Ber-

4 Bert Roest, A History of Franciscan Education (Leiden: Brill, 2000), 126.

5 Bonaventure, Commentaria in quattuor libros Sententiarum Magistri Petri Lombardi: in librum II (Turnhout: Brepols, 2011), Prologue, Lib II, d 23, a 2, q e (II, 547).

6 Keenan B. Osborne, 'Alexander of Hales,' in The History of Franciscan Theology, ed. Kenan B. Osborne (St Bonaventure: The Franciscan Institute, 2007) 1-38.

7 Philipp W. Rosemann, The Story of a Great Medieval Book: Peter Lombard's Sentences (Toronto: University of Toronto Press, 2007).

8 Neslihan Senocak, The Poor and the Perfect: The Rise of Learning in the Franciscan Order 12091310 (Ithaca: Cornell, 2012).

9 Victorin Doucet, 'Prolegomena in librum III necnon in libros I et II "Summa Fratris Alexandri",' in Doctoris irrefragabilis Alexandri de Hales Ordinis minorum Summa theologica, vol. 4 (Quaracchi: Collegium S. Bonaventurae, 1948); Victorin Doucet, 'The History of the Problem of the Summa,' Francis- 
nard Klumper, had insisted on denying, in the face of mounting evidence against a single author. As Doucet showed, however, the first and fourth tomes were likely authored primarily by Alexander's chief collaborator, John of La Rochelle, who had plans to prepare a Summa of his own before Alexander entered the order and his services became otherwise enlisted. Most probably, tomes 2 and 3 were prepared by a third redactor, who worked on the basis of John and Alexander's authentic works but did not always follow them exactly.

The multiple authorship has been one reason for the Summa's neglect, as modern scholars have tended to focus on single-authored works by a known author. However, the Summa Halensis is significant precisely because it represents the 'collective mind' of the founders of the Franciscan intellectual tradition at Paris and their attempt to articulate the contours of this tradition for the very first time. ${ }^{10}$ Far from a compilation of relatively disjoined sections, the Summa exhibits remarkable coherence and an overarching vision, and it contains many ideas that would quickly become defining features of Franciscan thought.

This is confirmed by manuscript evidence, which illustrates that the first three volumes were received as a whole following the deaths of John and Alexander in 1245. ${ }^{11}$ Such evidence is strengthened by the fact that only two small additions and no major corrections were made to these volumes in 1255-6, when Pope Alexander IV ordered William of Melitona, then head of the Franciscan school at Paris, to enlist any help he needed from learned friars to complete the last volume on the sacraments, which was not composed by Alexander and John and has yet to be prepared in a modern critical edition. ${ }^{12}$

Because of its collaborative nature, the Summa ultimately resulted in an entirely unprecedented intellectual achievement. There were of course other great works of a systematic nature that did precede it, including many Commentaries on Lombard's Sentences and other early Summae like the Summa aurea of William of Auxerre and the Summa de bono of Philip the Chancellor. However, the text that is by far the largest among these, namely, the Summa aurea, contains only 818 questions for discussion by comparison to the Summa's 3,408, as Ayelet Even-Ezra shows in her contribution to these volumes. There is virtually no comparison between the Summa and earlier texts.

can Studies 7 (1947): 26 - 41; Victorin Doucet, 'The History of the Problem of the Summa (Continued),' Franciscan Studies 7 (1947), 274-312.

10 Etienne Gilson, History of Christian Philosophy in the Middle Ages (London: Sheed and Ward, 1955), 327-31.

11 Victorin Doucet, 'The History of the Problem of the Summa,' 296-302. See also Palemon Glorieux, 'Les années 1242-1247 à la Faculté de Théologie de Paris,' Recherches de théologie ancienne et médiévale 29 (1962), 234-49.

12 Robert Prentice, O.F.M., 'The De fontibus paradisi of Alexander IV on the Summa Theologica of Alexander of Hales,' Franciscan Studies 5 (1945), 350 -1. The additions include SH 1, De missione visibili, 514-18; 2: De corpore humano, 501-630; De coniuncto humano, 631-784. 
In many respects, it was the first major contribution to the Summa genre for which scholasticism became famous and a prototype for further instalments in the genre, such as Thomas Aquinas' magisterial Summa Theologiae, which only began to be composed twenty years after the Summa Halensis was completed. Although Thomas Aquinas took a different view from his Franciscan counterparts on many issues, a comparison of the two texts shows that he adopted many topics of discussion from them which indeed became common topics of scholastic discussion more generally. For example, he inherited the idea for his famous 'five ways' to prove God's existence, the notion of eternal law, his account of the passions, and a structure for dealing with questions on the soul.

A major reason for the unprecedented size and scope of the Summa is that it incorporated an unmatched number of sources into its discussions. These included the traditional patristic sources that can be found in Peter Lombard's Sentences, along with the newly translated Greek patristic sources of Pseudo-Dionysius and John of Damascus, whom Lombard had begun to use in a preliminary way. The Summists also engage with more recent sources from the $11^{\text {th }}$ and $12^{\text {th }}$ centuries, including Anselm of Canterbury, whose works had largely been neglected until Alexander and his colleagues took an interest in them, as well as Hugh and Richard of St Victor and Bernard of Clairvaux. The Summa even maintains a dialogue with earlier contemporaries like William and Philip the Chancellor.

Of special note amongst the Summa's sources are many philosophical texts that had recently become available in the West in Latin translations. This in fact is one reason why the size of the Summa mushroomed so significantly, namely, because it was the first systematic treatise comprehensively to incorporate philosophical questions-about the nature of reality and knowledge for instance-into its treatment of how the world comes from and relates to its divine source. This is also a significant respect in which it set the agenda and terms of further scholastic debate. A common misperception of the scholastic period is that the incorporation of philosophy into the scope of theological inquiry was due largely to the rediscovery of Aristotle. This may have been true for the generation of Aquinas, but there was a period of about 100 years, between 1150 and 1250, when Latin access to Aristotle was patchy and riddled with problems.

A basic problem concerned the fact that the Aristotelian translations from Greek were not perceived to be of a high quality, and they were sometimes partial and were not produced all at once. For this reason, scholars during this period tended to rely much more heavily on the readily available work of the Islamic scholar Avicenna, whose writings translated from Arabic were of a much higher quality and became available all, between 1152 and 1166. Although Avicenna took Aristotle's texts as a point of departure, he proceeded from there to develop a system of thought that is nonetheless incommensurable with Aristotle's and in many respects advances beyond it, not least by incorporating a Neo-Platonic dimension. At the time, the Neo-Platonist reading of Aristotle was not uncommon, as it had long been proffered 
in the Greek and Arabic commentary traditions on Aristotle, not least on the basis of spurious Aristotelian works like The Theology of Aristotle.

Although Latin thinkers did not have this work until the Renaissance, they possessed a variation on it in the Liber de causis, which Aquinas realized in 1268 was actually a compilation based on Proclus' Elements of Theology rather than an authentic work of Aristotle himself. Such Neo-Platonizing works legitimized the reading of Aristotle in line with Avicenna. Furthermore, they justified projecting ideas from Avicenna on to Christian Neo-Platonists like Augustine, who was reconciled with Aristotle by means of Avicenna as well. In this connection, early scholastics and especially Franciscans relied particularly heavily on spurious Augustinian works, such as De spiritu et anima, De fide ad Petram, De ecclesiasticis dogmatibus, which lent themselves to interpretation in terms of Avicenna's thinking.

While the Franciscans were by no means exceptional in making use of Avicenna at the time, they were by far the most predominant school of thought to do so; and indeed, their incorporation of Avicennian themes was far more extensive than many of their contemporaries. In the case of the Franciscans particularly, there appears to have been a sort of happy coincidence between the Avicennian materials that were available and popular at the time and what was well-suited to articulating a distinctly Franciscan form of thought. Francis had been more emphatic than most in insisting on the radical dependence of all things on God and the necessity of his guidance in human knowing. Avicenna aided the first Franciscan intellectuals to give an account of philosophical and theological matters that respected his values. This presumably went a long way towards justifying to members of the order itself that there was a place for high-level intellectual pursuits in their life. ${ }^{13}$

That is not to say that Franciscan thought is a function of Avicenna or any other authority. While Avicenna in many cases provided important philosophical resources for Franciscan thinking, these were always adapted to suit Franciscan and more broadly Christian purposes, as well as supplemented with insights from other sources in the Christian and even the Islamic and Jewish traditions that resonated with the Franciscan ethos. The ultimate product of these synthesising efforts was a systematic framework for thinking that was entirely the invention of early Franciscans. Although it incorporates many authorities, consequently, the Summa cannot rightly be described as a mere attempt to rehearse or systematize any authority, including the authority of authorities, Augustine.

13 According to the early $20^{\text {th }}$-century medievalist, Étienne Gilson, the appropriation of Avicenna was the key to Franciscan efforts to 'systematize' the work of Augustine, whose intellectual tradition had prevailed for most of the earlier Middle Ages. The Franciscans sought to do this, in Gilson's opinion, in order to give Augustine's legacy a chance of surviving the competition that was increasingly posed by the popularization of works by Aristotle. See Étienne Gilson, 'Les sources Greco-arabes de l'augustinisme avicennisant,' Archives d'histoire doctrinale et littéraire du Moyen Age 4 (1929): 5-107; Étienne Gilson, 'Pourquoi saint Thomas a critiqué saint Augustin,' Archives d'histoire doctrinale et littéraire du Moyen Age 1 (1926-7): 5-127. 
In this connection, it is worth noting that the Summa is not exceptional in making extensive use of Augustine. All major thinkers at the time, from Anselm and Hugh of St Victor to Peter Lombard and Thomas Aquinas, also gave disproportional weight to Augustine's authority. The reason for citing Augustine in such cases was not simply to interpret or bolster his own views, however. Rather, references to Augustine were marshalled as proof texts to lend support to the author's own perspectives, regardless of whether those coincided with authentic views of Augustine. This was standard and even required practice at a period in time when the accepted method of advancing one's own arguments involved situating them in relation to a broader, if loosely defined, tradition or authority for thought.

As Mary Carruthers rightly notes, authorities in this period were not so much thinkers but texts; and texts were subject to interpretation, with their meanings always capable of being brought out in new ways in new contexts. What rendered any given text authoritative was precisely whether it gave rise to such new readings, which in turn became part of the meaning or tradition of the text. ${ }^{14}$ Although scholastic authors generally invoked authorities with a view to bolstering their own agendas, that does not mean there were not cases, including in the Summa, where they sought to represent the position of a particular authority fairly accurately. ${ }^{15}$ In such cases, however, there was generally a coincidence between the views presented by an authority and those of the scholastic author, who was still working for his own intellectual ends, which remained the ultimate arbiter of his use of sources. In spite of this, a tendency remains to take scholastic quotations from authorities at face value, thus interpreting texts like the Summa Halensis as more or less the sum or function of their sources.

\section{The Objectives of this Volume}

This volume offers a corrective to that tendency in the form of contributions which examine in detail how the Summa reckons with some of the most significant sources of the time, including the Bible (Gies), Augustine (Schumacher), Pseudo-Dionysius (Edwards), John of Damascus (Cross, Zachhuber), Anselm of Canterbury and the Victorines (Canty, Rosato, Coolman), as well as some more covert influences like the $9^{\text {th }}$ century thinker John Scotus Eriugena (Kavanagh) and above all Avicenna (Bertolacci, Schumacher). Further contributions situate the Summa in its historical and intellec-

14 As Mary Carruthers has observed in The Book of Memory: A Study of Memory in Medieval Culture (Cambridge: Cambridge University Press, 1990), 262.

15 Mary Carruthers, The Book of Memory, 235. Marcia L. Colish, 'The Sentence Collection and the Education of Professional Theologians in the Twelfth Century,' in The Intellectual Climate of the Early University: Essays in Honor of Otto Grundler, ed. Nancy Van Deusen (Kalamazoo: Western Michigan University, 1997), 1-26, esp. 11; Marcia L. Colish, 'Authority and Interpretation in Scholastic Theology,' in Marcia L. Colish, Studies in Scholasticism (Aldershot: Ashgate, 2006), 5. 
tual context, in some cases by locating it with reference to contemporaries like William of Auxerre and other early Summa authors (Brown, Even-Ezra), William of Auvergne (Smith), or even associates of the English Franciscan school (Gasper).

Finally, the Summa is placed in relation to later contributors to early Franciscan thought like Odo Rigaldus (Delmas) and to the Franciscan religious order and rule more generally (Şenocak). From different perspectives, consequently, these contributions highlight what an exceptional text the Summa was in its context and how it deployed sources to construct what was at the time an entirely novel Franciscan intellectual tradition, which laid the foundation for the work of Franciscans for generations to follow. By illustrating the Summa's novelties, in fact, this study provides grounds for identifying continuity where scholars have always seen a break between the earlier Franciscan tradition and the new departures of John Duns Scotus and his generation.

This not only shifts the credit for some of Scotus' innovations back on to his predecessors but also highlights more clearly the Franciscan ethos that underlies his work, which shines most clearly through the study of early Franciscan thought. In that sense, the study of the Summa Halensis clearly demarcates Franciscan thought from any modern developments in intellectual history which took place outside the order, exonerating it of the charges some have laid before them of causing all the alleged ills of modernity. At the same time, this study helps to clarify how Franciscan ideas were meant to be construed and employed on their own terms and the promise they might hold for reckoning with philosophical and theological problems today. To make such a recovery of the Franciscan intellectual tradition possible in future is one ultimate objective of this project to highlight the tensions between authorities and innovation in early Franciscan thought. 
